\title{
The first record of the invasive mosquito species Aedes albopictus in Chişinău, Republic of Moldova, 2020
}

Tatiana Șuleșco ${ }^{1 *} \mathbb{D}$, Galina Bușmachiu' ${ }^{1}$ Unchana Lange ${ }^{2}$, Jonas Schmidt-Chanasit ${ }^{2,3}$ and Renke Lühken ${ }^{2^{*}}$

\begin{abstract}
Background: In Europe, Aedes albopictus is an important vector of chikungunya virus and Dirofilaria nematodes and has been involved in local autochthonous circulation of dengue and Zika viruses. Due to the ongoing spread, targeted field surveillance at potential points of entry of invasive Aedes mosquitoes was initiated by the Republic of Moldova in 2020 as part of the transboundary "Invasive Aedes Mosquitoes COST-Action project."

Methods: In 2020, ovitraps were positioned at each of three locations: the border crossing to Romania in Leuşeni (Hancesti region), Chişinău International Airport and Chişinău Botanical Garden.

Results: A total of 188 Aedes spp. eggs were collected at the Chişinău International Airport between August and September 2020. Twenty-three adults reared in the laboratory were identified morphologically as Ae. albopictus (Skuse, 1895), and 12 selected specimens were confirmed by molecular barcoding of the cytochrome oxidase subunit I gene region. In addition, one adult Ae. albopictus female at the same site was caught with a manual aspirator.

Conclusions: This is the first documented report of Ae. albopictus in the Republic of Moldova. The presence of immature and adult stages indicates the local reproduction of the species in the country. Therefore, it is crucial to extend and strengthen surveillance of the invasive Aedes mosquitoes to prevent Ae. albopictus and other exotic mosquito species from becoming established in the Republic of Moldova.
\end{abstract}

Keywords: Aedes albopictus, Asian tiger mosquito, Invasive species, Entomological survey, Republic of Moldova

\footnotetext{
*Correspondence: tatiana_sulesco@yahoo.com; luehken@bnitm.de

${ }^{1}$ Laboratory of Entomology, Institute of Zoology, MD-2028 Chişinău, Republic of Moldova

2 Department of Arbovirology, Bernhard Nocht Institute for Tropical Medicine, Bernhard-Nocht-Str. 74, 20359 Hamburg, Germany

Full list of author information is available at the end of the article
}

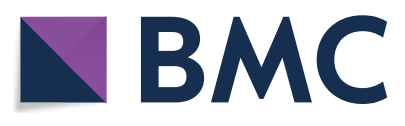

(c) The Author(s) 2021. Open Access This article is licensed under a Creative Commons Attribution 4.0 International License, which permits use, sharing, adaptation, distribution and reproduction in any medium or format, as long as you give appropriate credit to the original author(s) and the source, provide a link to the Creative Commons licence, and indicate if changes were made. The images or other third party material in this article are included in the article's Creative Commons licence, unless indicated otherwise in a credit line to the material. If material is not included in the article's Creative Commons licence and your intended use is not permitted by statutory regulation or exceeds the permitted use, you will need to obtain permission directly from the copyright holder. To view a copy of this licence, visit http://creativecommons.org/licenses/by/4.0/. The Creative Commons Public Domain Dedication waiver (http://creativeco mmons.org/publicdomain/zero/1.0/) applies to the data made available in this article, unless otherwise stated in a credit line to the data. 


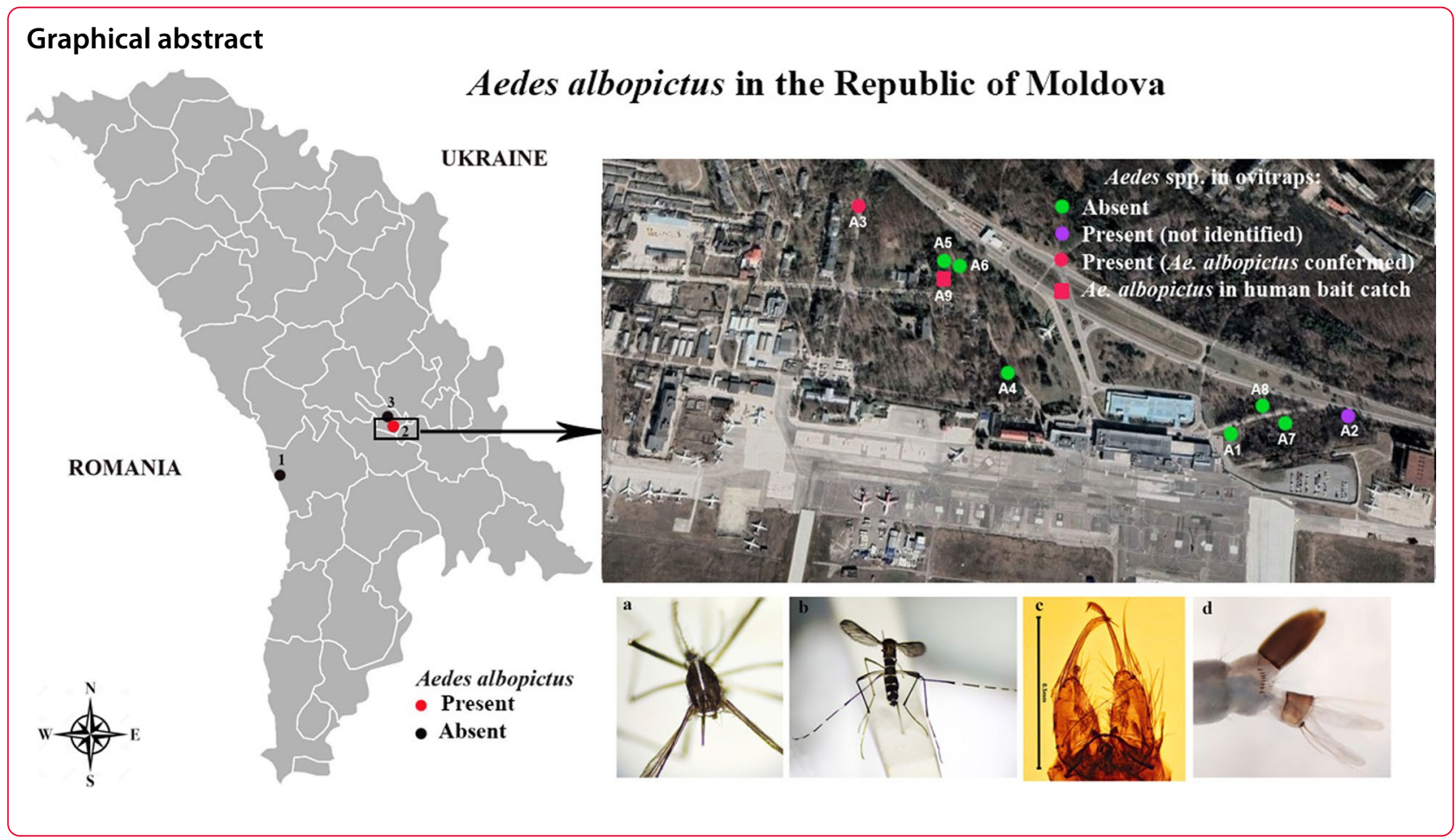

Aedes albopictus (Skuse, 1895), commonly known as Asian tiger mosquito, is an invasive mosquito species native to tropical and subtropical regions of Southeast Asia and the Indian Ocean [1]. Over the last 4 decades, the species rapidly expanded its distributional range worldwide including in the Americas, Africa, Australia and Europe [2]. Experimental and field data demonstrated that Ae. albopictus is a potential vector of $>30$ different pathogens $[1,3,4]$. In Europe, Ae. albopictus is an important vector of chikungunya virus with several outbreaks having occurred in Italy [5, 6] and France [7-9] and Dirofilaria nematodes [10]. In addition, the species was involved in local autochthonous circulation of dengue virus [11-13] and Zika virus [14] in Europe.

Globalization, with increasing international trade and travel, facilitates the spread of Ae. albopictus. Due to its ecological plasticity [1], Ae. albopictus has invaded and become established in 30 countries in Europe including the neighboring regions of the Republic of Moldova in the Mediterranean Basin, the Thrace region of Turkey and the eastern Black Sea coast [15-17]. Recently, the species was introduced to the the northern Black Sea coast of the Crimean Peninsula [18]. The first report of Ae. albopictus in Romania, a neighboring country to the Republic of Moldova, was in Bucharest in 2012 [19]. Further sampling efforts demonstrated the spread of $A e$. albopictus in the country, including the Constanta region, where positive sampling sites were close to the border of Moldova [20].

The global trade of lucky bamboo (Dracaena sp.) and tires is the most important pathway for the global dispersal of invasive Aedes species [21, 22]. Subsequently, public and private transport especially along highways is considered one of the main drivers of Ae. albopictus's spread in Europe [23-27]. Thus, targeted field surveillance of potential points of entry (PoE) for Ae. albopictus and other invasive Aedes mosquitoes (AIM) at a highway, botanical garden and airport was carried out in 2020 in the Republic of Moldova as part of the "AIM-COST action project" [28].

Field surveys were conducted at three locations that were potential routes of entry to the Republic of Moldova for invasive Aedes mosquito species. These included the border crossing to Romania in Leuşeni, Hâncești region (10 June-16 October 2020), where the border inspection post is located in an agricultural environment and international vehicular transport regularly enters the country, Chişinău International Airport (5 July-31 October 2020) and Chişinău Botanical Garden (10 July-16 October 2020), known for introducing and growing tropical plants (Fig. 1). Conicalshaped black plastic containers (height: $13 \mathrm{~cm}$, lower diameter: $9 \mathrm{~cm}$, upper diameter: $13 \mathrm{~cm}$ ) with approximately 1-1 volume were used as ovitraps [15]. Each trap 


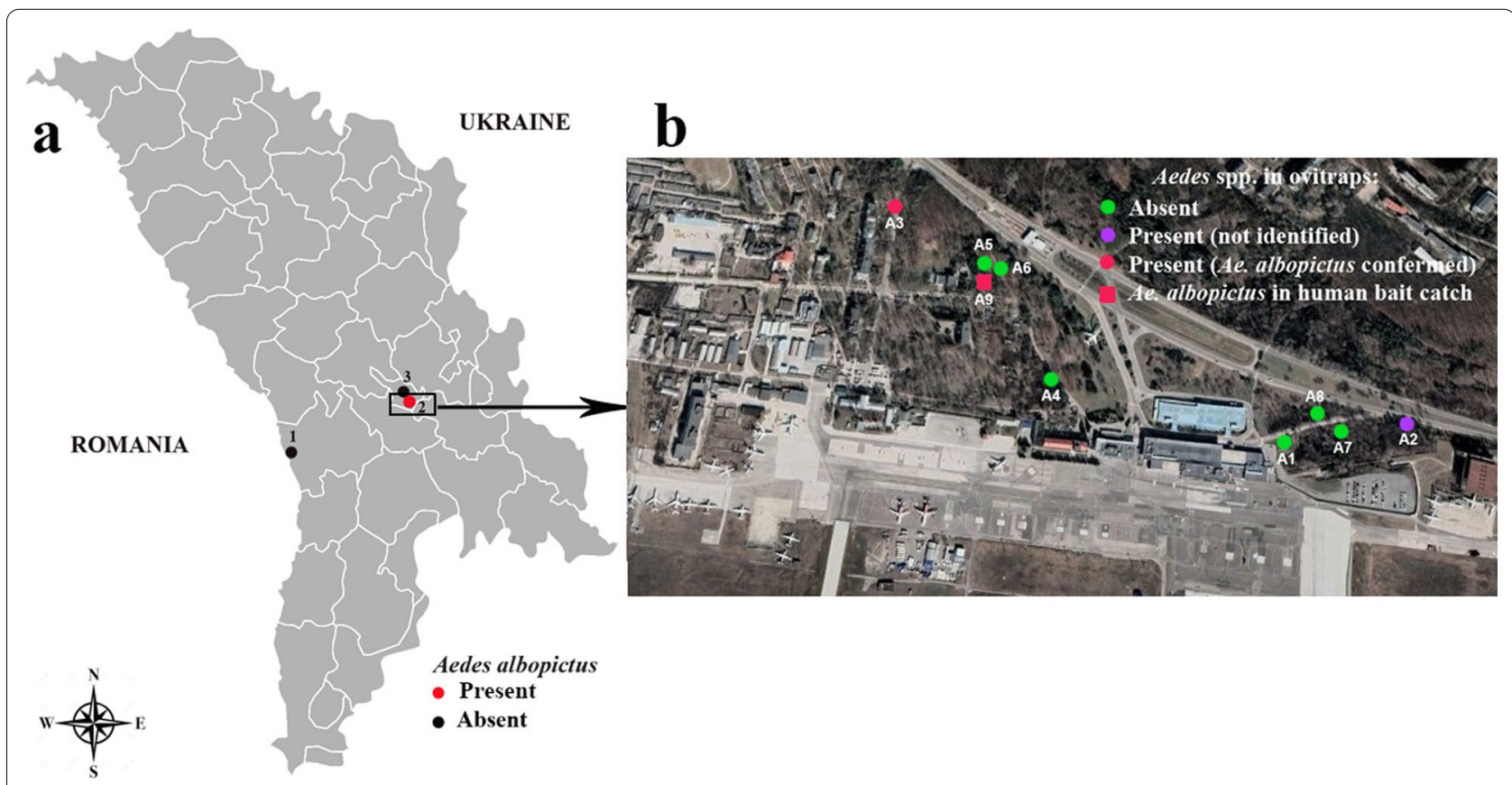

Fig. 1 Study area. a Sampling locations in the Republic of Moldova: 1: the border crossing to Romania in Leuşeni; 2: Chişinău International Airport; 3: Chişinău Botanical Garden. b Sampling sites at Chişinău International Airport

was filled two thirds with clean water, and scratched tongue depressors $(1.7 \times 15 \mathrm{~cm})$ were added as an egglaying substrate for invasive Aedes species. Five ovitraps were positioned in each location in the shaded sites at a distance not less than $20 \mathrm{~m}$ from each other, and the maximum distance between traps was about $400 \mathrm{~m}$. (Fig. 1). The tongue depressors and water were collected from the traps and replaced with clean water and new tongue depressors every 2 weeks. All samples were transported to the Entomology Laboratory, Institute of Zoology, in Chișinău for rearing of eggs and larvae to adults in trays containing dechlorinated water. Hatched larvae were fed with aquarium fish food (ASTRA Aquaristik $\mathrm{GmbH}$, Osnabrück, Germany). Morphological species identification of larvae and adults was conducted with the keys in Becker et al. [29].

Two mosquito taxa were collected from the ovitraps during the entomological surveys: Culex pipiens (sensu

Table 1 Aedes spp. eggs with confirmed Ae. albopictus specimens and Cx. pipiens (s.l.)/Cx. torrentium larvae collected from 15 ovitraps at three sampling locations in the Republic of Moldova, 2020

\begin{tabular}{|c|c|c|c|}
\hline Location & Aedes spp. eggs & $\begin{array}{l}\text { Hatched Aedes spp. (confirmed as Ae. albopictus by morphology/ } \\
\text { tested and confirmed by COI barcoding) }\end{array}$ & $\begin{array}{l}\text { Culex pipiens } \\
(\text { s.I.)/CX. } \\
\text { torrentium }\end{array}$ \\
\hline \multicolumn{4}{|c|}{ Airport, Chişinău } \\
\hline $\mathrm{A} 1$ & & & 59 \\
\hline $\mathrm{A} 2$ & 21 & 0 & \\
\hline $\mathrm{A} 3$ & 167 & $23(23 / 12)$ & \\
\hline \multicolumn{4}{|c|}{ Botanical garden, Chişinău } \\
\hline B1 & & & 28 \\
\hline B2 & & & 20 \\
\hline \multicolumn{4}{|c|}{ Leuşeni, Hânceşti } \\
\hline $\mathrm{C} 1$ & & & 15 \\
\hline $\mathrm{C} 2$ & & & 83 \\
\hline Total & 188 & 23 & 205 \\
\hline
\end{tabular}




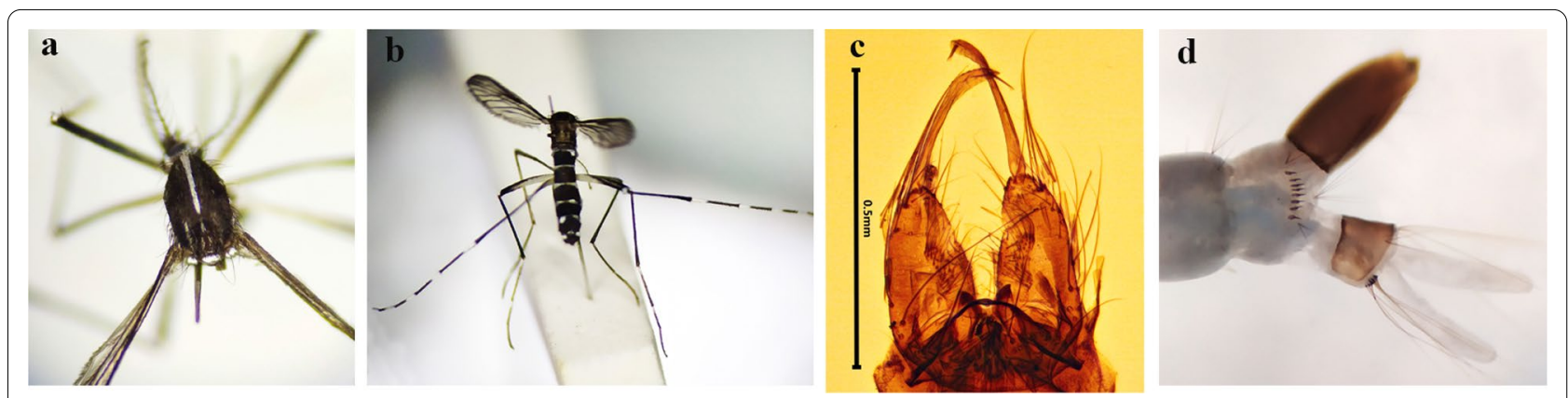

Fig. 2 Specimens of Aedes albopictus collected at the Chişinău International Airport in 2020. a Adult female, pattern on scutum; b adult female, dorsal view, c male genitalia; d fourth-instar larva

lata)/Cx. torrentium (205 individuals) and Aedes spp. (188 eggs) (Table 1). Culex pipiens (s.l.)/Cx. torrentium was present at all three study locations, while Aedes spp. eggs were only collected at Chişinău International Airport. Two ovitraps positioned in the forest square close to the airport collected 188 Aedes spp. eggs. The first positive ovitrap (A3: latitude 46.938, longitude 28.928, altitude $80 \mathrm{~m}$ ) yielded 167 eggs: 72 eggs (21 August), 38 eggs (5 September) and 57 eggs (27 September). The second trap (A2: latitude 46.936, longitude 28.940, altitude $80 \mathrm{~m}$ ) collected 21 Aedes spp. eggs on 27 September. Twenty-three specimens (19 females and 4 males) were successfully reared from the Aedes spp. eggs to adult stage and identified as Ae. albopictus by larval and adult morphology (Fig. 2). Morphological identification of $A e$. albopictus was confirmed by molecular barcoding of the cytochrome oxidase subunit I gene region of 12 randomly selected specimens [30]. All sequences were entered into GenBank (accession no. MZ069031-MZ069042). In addition, one Ae. albopictus female was caught by manual aspirator during ovitrap inspection at the airport on 27 September (Fig. 1b). Three additional ovitraps (A6, A7, A8) were placed at the Chișinău International Airport at the end of September and surveillance continued through to 31 October, but no further Aedes spp. eggs were collected.

Surveillance of the presence/absence of invasive Aedes species at the potential PoE in the Republic of Moldova demonstrated the presence of Ae. albopictus at the Chişinău International Airport. In the past, only few studies have been dedicated to the role of European airports in importing exotic mosquito species with $A e$. albopictus recorded at Schiphol Airport, The Netherlands [31-34].

The introduction of Ae. albopictus in Europe was facilitated by passive dispersion through the global transportation of tires $[35,36]$ and the import of Dracaena plants known as "lucky bamboo," e.g., in The Netherlands [21] and Bulgaria [37]. Further dispersal in Europe inside vehicles via highway systems was documented in Switzerland [38], Germany [23], Spain [24] and the UK [26]. However, no exotic mosquito species were detected at the border crossing between Romania and Chişinău and at the botanical garden.

This study emphasizes the importance of air transportation for the dispersal of Ae. albopictus in Europe. This is the first documented report of Ae. albopictus in the Republic of Moldova to our knowledge, and the presence of adult and immature stages indicates the local reproduction of the species. Further investigations with greater trapping efforts are necessary to clarify whether this is a stable, established population. This is especially important for determining future mosquito control measures; public health authorities were informed, but insecticidal control has not yet been implemented. In addition, with the increasing spread and population densities of Ae. albopictus in Europe, additional introductions have to be expected via air traffic and other routes of entry, which may allow long-term establishment. Therefore, it is crucial to extend and strengthen surveillance of invasive Aedes mosquitoes to prevent their establishment and future arbovirus transmission in the Republic of Moldova.

Abbreviations

PoE: Points of entry; AIM: Aedes invasive mosquitoes.

\section{Acknowledgements}

The work was done within the framework of the AIM-COST Action CA17108.

\section{Authors' contributions}

TȘ designed the study. TȘ, GB, UL and RL conducted the field and laboratory work. TS and RL prepared the manuscript. GB, UL and JSC contributed to the discussion and improvement of the manuscript. All authors read and approved the final manuscript.

\section{Funding}

Open Access funding enabled and organized by Projekt DEAL. This work was financially supported by the Institute of Zoology, Republic of Moldova under the project EVOLANTER (project no. 20.80009.7007.02) and the Federal 
Ministry of Education and Research of Germany (BMBF) under the project NEED (grant no. 01 KI2022).

\section{Availability of data and materials}

All data generated or analyzed during this study are included in this published article

\section{Declarations}

Ethics approval and consent to participate

Not applicable.

\section{Consent for publication}

Not applicable.

\section{Competing interests}

The authors declare that they have no competing interests.

\section{Author details}

${ }^{1}$ Laboratory of Entomology, Institute of Zoology, MD-2028 Chişinău, Republic of Moldova. ${ }^{2}$ Department of Arbovirology, Bernhard Nocht Institute for Tropical Medicine, Bernhard-Nocht-Str. 74, 20359 Hamburg, Germany. ${ }^{3}$ Faculty of Mathematics, Informatics and Natural Sciences, Universität Hamburg, Hamburg, Germany.

Received: 13 May 2021 Accepted: 12 October 2021

Published online: 03 November 2021

\section{References}

1. Paupy C, Delatte H, Bagny L, Corbel V, Fontenille D. Aedes albopictus, an arbovirus vector: from the darkness to the light. Microbes Infect. 2009;11:1177-85.

2. Kraemer MU, Sinka ME, Duda KA, Mylne A, Shearer FM, Barker CM, et al. The global distribution of the arbovirus vectors Aedes aegypti and $A$. albopictus. Elife. 2015. https://doi.org/10.7554/eLife.08347.

3. Vanlandingham D, Higgs S, Huang Y-J. Aedes albopictus (Diptera: Culicidae) and mosquito-borne viruses in the United States. J Med Entomol. 2016;53:1024-8

4. Pereira-dos-Santos T, Roiz D, Lourenço-de-Oliveira R, Paupy C. A systematic review: is Aedes albopictus an efficient bridge vector for zoonotic arboviruses? Pathogens. 2020. https://doi.org/10.3390/pathogens9 040266.

5. Rezza G, Nicoletti L, Angelini R, Romi R, Finarelli AC, Panning M, et al. Infection with chikungunya virus in Italy: an outbreak in a temperate region. Lancet. 2007. https://doi.org/10.1016/S0140-6736(07)61779-6.

6. Venturi G, Luca M, Fortuna C, Remoli ME, Riccardo F, Severini F, et al. Detection of a chikungunya outbreak in Central Italy, August to September 2017. Euro Surveill. 2017. https://doi.org/10.2807/1560-7917.ES.2017. 22.39.17-00646

7. Grandadam M, Caro V, Plumet S, Thiberge JM, Souares $Y$, Failloux AB, et al. Chikungunya virus, southeastern France. Emerg Infect Dis. 2011;17:910-3. https://doi.org/10.3201/eid1705.101873.

8. Delisle E, Rousseau C, Broche B, Leparc-Goffart I, L'Ambert G, Cochet A, et al. Chikungunya outbreak in Montpellier, France, September to October 2014. Euro Surveill. 2015. https://doi.org/10.2807/1560-7917.ES2015. 20.17.21108.

9. European Centre for Disease Prevention and Control (ECDC). Autochthonous transmission of chikungunya virus in EU/EEA, 2007-2020 Stockholm. 2020. https://www.ecdc.europa.eu/en/all-topics-z/chiku ngunya-virus-disease/surveillance-and-diseasedata/autochthonous-trans mission. Accessed 27 Aug 2021

10. Cancrini G, Scaramozzino P, Gabrielli S, Di Paolo M, Romi TL. Aedes albopictus and Culex pipiens implicated as natural vectors of Dirofilaria repens in central Italy. J Med Entomol. 2007:44:1064-6.

11. Schmidt-Chanasit J, Haditsch M, Schoneberg I, Günther S, Stark K, Frank C. Dengue virus infection in a traveller returning from Croatia to Germany. Euro Surveill. 2010. https://doi.org/10.2807/ese.15.40.19677-en.pii= 19677.
12. Succo T, Leparc-Goffart I, Ferre JB, Roiz D, Broche B, Maquart M, et al. Autochthonous dengue outbreak in Nimes, south of France, July to September 2015. Euro Surveill. 2016. https://doi.org/10.2807/1560-7917. ES.2016.21.21.30240.pii=30240.

13. European Centre for Disease Prevention and Control (ECDC). Autochthonous cases of dengue in Spain and France, 1 October 2019. Stockholm. 2019. https://www.ecdc.europa.eu/en/publications-data/rapid-risk-asses sment-autochthonous-cases-dengue-spainand-france. Accessed 27 Aug 2021.

14. Giron S, Franke F, Decoppet A, Cadiou B, Travaglini T, Thirion L, et al. Vector-borne transmission of Zika virus in Europe, southern France, August 2019. Euro Surveill. 2019. https://doi.org/10.2807/1560-7917.ES. 2019.24.45.1900655.

15. Bellini R, Michaelakis A, Petrić D, Schaffner F, et al. Practical management plan for invasive mosquito species in Europe: I. Asian tiger mosquito (Aedes albopictus). Travel Med Infect Dis. 2020. https://doi.org/10.1016/j. tmaid.2020.101691.

16. Akiner MM, Demirci B, Babuadze G, Robert V, Schaffner F. Spread of the invasive mosquitoes Aedes aegypti and Aedes albopictus in the Black Sea region increases risk of chikungunya, dengue, and Zika outbreaks in Europe. PLOS Negl Trop Dis. 2016. https://doi.org/10.1371/journal.pntd. 0004664.

17. Ganushkina LA, Patraman IV, Rezza G, Migliorini L, Litvinov SK, Sergiev VP. Detection of Aedes aegypti, Aedes albopictus, and Aedes koreicus in the area of Sochi. Russia Vector Borne Zoonotic Dis. 2016. https://doi.org/10. 1089/vbz.2014.1761.

18. Kovalenko IS, Yakunin SN, Abibulaev DE, Vladychak V, Boroday NV, Smelyansky VP, et al. Reporting of Aedes (Stegomyia) albopictus (Skuse, 1895) in the territory of Crimea. Problemy Osobo Opasnykh Infektsii. 2020. https://doi.org/10.21055/0370-1069-2020-2-135-137.

19. Prioteasa LF, Dinu S, Falcuțe E, Ceianu CS. Established population of the invasive mosquito species Aedes albopictus in Romania, 2012-14. J Am Mosq Control Assoc. 2015;31:177-81.

20. Fălcuță E, Prioteasa LF, Horváth C, Pastrav IR, Schaffner F, Mihalca AD. The invasive Asian tiger mosquito Aedes albopictus in Romania: towards a country-wide colonization? Parasitol Res. 2020;119:841-5.

21. Scholte E, Jacobs F, Linton Y, Dijkstra E, Fransen J, Takken W. First record of Aedes (Stegomyia) albopictus in the Netherlands. Eur Mosq Bull. 2007;22:5-9.

22. Schaffner F, Bortel WV, Coosemans EM. First record of Aedes (Stegomyia) albopictus in Belgium. J Am Mosq Control Assoc. 2004;20(2):201-3.

23. Pluskota B, Storch V, Braunbeck T, Beck M, Becker N. First record of Stegomyia albopicta (Skuse) (Diptera: Culicidae) in Germany. Eur Mosq Bull. 2008;26:1-5.

24. Collantes F, Delacour S, Alarcón-Elbal PM, Ruiz-Arrondo I, Delgado JA, Torrell-Sorio A, et al. Review of ten-years presence of Aedes albopictus in Spain 2004-2014: known distribution and public health concerns. Parasit Vectors. 2015. https://doi.org/10.1186/s13071-015-1262-y.

25. Flacio E, Engeler L, Tonolla M, Müller P. Spread and establishment of Aedes albopictus in southern Switzerland between 2003 and 2014: an analysis of oviposition data and weather conditions. Parasit Vectors. 2016. https:// doi.org/10.1186/s13071-016-1577-3.

26. Medlock JM, Vaux AGC, Cull B, Schaffner F, Gillingham E, Pfluger V, Leach S. Detection of the invasive mosquito species Aedes albopictus in southern England. Lancet Infect Dis. 2017;17:140.

27. Goiri F, González MA, Goikolea J, Oribe M, de Castro V, Delacour S, et al. Progressive invasion of Aedes albopictus in Northern Spain in the period 2013-2018 and a possible association with the increase in insect bites. Int J Environ Res Public Health. 2020;17:1678. https://doi.org/10.3390/ijerp h17051678.

28. Aedes Invasive Mosquitoes (AIM) COST Action. https://www.aedescost. eu/. Accessed 16 April 2021.

29. Becker N, Petric D, Zgomba M, Boase C, Madon M, Dahl C, Kaiser A. Mosquitoes and their control. New York: Springer; 2010.

30. Fang Y, Shi WQ, Zhang Y. Molecular phylogeny of Anopheles hyrcanus group (Diptera: Culicidae) based on mtDNA COI. Infect Dis Poverty. 2017. https://doi.org/10.1186/s40249-017-0273-7. 
31. Becker N, Geier M, Balczun C, Bradersen U, Huber K, Kiel E, et al. Repeated introduction of Aedes albopictus into Germany, July to October 2012. Parasit Res. 2013;112(4):1787-90.

32. Scholte EJ, Ibañez-Justicia A, Stroo A, De Zeeuw J, den Hartog W, Reusken C. Mosquito collections on incoming intercontinental flights at Schiphol International airport, the Netherlands, 2010-2011. J Eur Mosq Control Assoc. 2014;32:17-21.

33. Ibáñez-Justicia A, Smitz N, den Hartog W, van de Vossenberg B, De Wolf K, Deblauwe I, et al. Detection of exotic mosquito species (Diptera: Culicidae) at international airports in Europe. Int J Env Res Pub He. 2020. https://doi.org/10.3390/ijerph17103450.

34. Horváth C, Cazan C, Mihalca A. Emergence of the invasive Asian bush mosquito, Aedes (Finlaya) japonicus japonicus, in an urban area. Romania Parasit Vectors. 2021. https://doi.org/10.1186/s13071-021-04698-2.

35. Adhami J, Reiter P. Introduction and establishment of Aedes (Stegomyia) albopictus Skuse (Diptera: Culicidae) in Albania. J Am Mosq Control Assoc. 1998; 14(3):340-3.
36. Dalla Pozza G, Majori G. First record of Aedes albopictus establishment in Italy. J Am Mosq Control Assoc. 1992;8:318-20.

37. Mikov O, Nikolov G, Schaffner F, Mathis A. First record and establishment of Aedes albopictus in Bulgaria. In: VBORNET-EMCA Joint Meeting 'Invasive Mosquitoes and Public Health in the European Context', 28-29 November 2013. EMCA: Antwerp; 2013.

38. Flacio E, Lüthy P, Patocchi N, Guidotti F, Tonolla M, Peduzzi R. Primo ritrovamento di Aedes albopictus in Svizzera. Boll Della Soc Ticinese Sci Nat. 2004;92:141-2.

\section{Publisher's Note}

Springer Nature remains neutral with regard to jurisdictional claims in published maps and institutional affiliations.
Ready to submit your research? Choose BMC and benefit from:

- fast, convenient online submission

- thorough peer review by experienced researchers in your field

- rapid publication on acceptance

- support for research data, including large and complex data types

- gold Open Access which fosters wider collaboration and increased citations

- maximum visibility for your research: over $100 \mathrm{M}$ website views per year

At BMC, research is always in progress.

Learn more biomedcentral.com/submissions 